\title{
The use of a rating instrument to teach and assess communication skills of health-care workers in a clinic in the Western Cape
}

M. Steyn

M.A.

\&

R. Borcherds

B.A.

$\&$

N. van der Merwe

B.A.

Professional Communication Unit, University of Cape Town
Research in health communication has shown the crucial role that communication plays in the successful treatment of a patient.

\section{Summary}

Research in health communication shows communication to be an important aspect of successful health-care. Moreover, training courses which provide feedback have been shown to improve health professionals' ability to conduct successful interviews. This article describes a rating instrument which was developed in order to facilitate teaching and assessing the communication aspects of health-care interviews. The instrument was found to be useful in a training programme offered to nursing staff of a TB Clinic in Mitchells Plain, Western Cape. The instrument appears as Table 1 . In the Table categories of communication behaviours, each indicating an important aspect of the interaction, are given as the six headings.

These are:

- establishing rapport and respect

- listening receptively

- confirming the patient

- sharing control

- informing effectively and checking perceptions.

Within each category the more detailed specific behaviours are listed, allowing for close analysis of a care-giver's interviewing skill. The article briefly discusses the importance in effective communication between the care-giver and patient of each category of behaviours given in the instrument, supported by evidence from research. Lastly the article describes a "case study" on how the instrument has been successfully used in a training programme.

\section{Opsomming}

Navorsing in gesondheidskommunikasie het getoon hoe belangrik kommunikasie in suksesvolle mediese sorg is. Daarbenewens het dit geblyk dat opleidingskursusse wat terugvoering voorsien gesondheidspersoneel se vermoë om suksesvolle onderhoude to voer, verbeter. In hierdie skripsie word 'n beoordelingskaal bekendgestel vir die aanleer en waardebepaling van kommunikasie-aspekte van gesondheids onderhoude. Die skaal bied 'n nuttige formaat waarop ' $n$ wye reeks onderhoude, vanuit die perspektief van 'n effektiewe patiënt-gesentreerde onderhoud, na waarde geskat kan word. Die skaal verskyn as Tabel 1. In die Tabel word kategorieë van kommunikasiegedrag onder ses opskrifte aangegee, waar elke kategorie ' $n$ belangrike aspek van die interaksie aandui.

Hulle is soos volg:

- om punte van ooreenkoms en respek vas te stel

- om met ontvanklikheid te luister

- om die patiënt goed te keur

- om kontrole te deel

- om waarnemings effektief oor te dra en na te gaan.

Binne elke kategorie word daar in meer besonderhede ' $n$ lys gemaak van die bepaalde gedrag wat nadere analise van 'n ondervraer se vaardigheid toelaat. Vir elke gedragskategorie wat in die skaal aangegee word, word die belangrikheid vir effektiewe kommunikasie tussen die versorger en patiënt kortliks bespreek, gesteun deur bewyse uit die navorsing. Die artikel beskryt ' $n$ studie waarin die instrument met sukses gebruik was. 


\section{Introduction}

Research in health communication has shown the crucial role that communication plays in the successful treatment of a patient (Ley 1982:241-254, DiMatteo et al 1986:581-594, Korsch 1989:5-9, Borcherds 1987:5-9, Thompson 1984:146-163). Patients lack the technical expertise to judge the quality of a health-care encounter from a diagnostic or therapeutic point of view. Their satisfaction with the encounter is based on their perception of and response to the quality of communication with the health-care provider (Street et al 1988:420-440, Street 1989:137-154). Moreover, such essential factors as patients' understanding, recall and adherence to therapy have all been linked to the communication style of the healthprovider (Ley 1982:241-254, Bush 1985:103-117). By contrast, ineffective interpersonal communication has been shown to lead to dissatisfaction with health-care services (Lane 1983:772799 ), and can result in alienation between health-care professionals and their patients (Korsch 1972:66-74).

In spite of the clear benefit of effective communication in successful healthcare interactions (Kreps 1988:344-359), the tendency among health-care professionals is still to interact with the patient in an authoritarian, disease-oriented manner, which leaves the patient's communication needs unsatisfied (Wyatt 1991:157-174), and comparatively little attention is paid to this aspect of their training (Korsch 1989:5-9).

There is much evidence that training courses can and do improve communication skills (Maguire et al 1978:695-704, Maguire et al 1986:1573-1578, Maguire 1990:215-216). Another finding is that students tend to be poor at judging their own ability to communicate, and need detailed explanation, feedback and practice regarding specific communication behaviours (Marteau et al 1991:127134). This also makes training demanding and time-consuming.

This article describes the rating system, or instrument, designed by the authors to facilitate and evaluate a training programme on the communication aspects of health-care interviews. This emphasis on the interpersonal communication between care-giver and patient is in line with the shift which is prevalent in much contemporary thinking towards a more holistic approach to medical care (Wyatt 1991:157-174, Reiser et al 1980, Livesey 1986). The objective of the training was to encourage the nurses to become more self-reflective by enabling them to learn and incorporate the complex range of communication behaviours that produce a positive interaction with patients. The rating instrument identifies specific behaviours which can make an interaction more patient-centred, and therefore more successful. The behaviours have been drawn from an analysis of research into the subject of communication between care-givers and patients, as well as from the authors' extensive personal experience in teaching communication skills to medical students, nurses and paramedics.

Although the instrument still needs to be validated, especially for cross-cultural application, the study shows that it facilitated training and that the participants were assessed with a good degree of reliability.

The instrument can be used both to provide feedback to students in a teaching situation, and for assessment of healthcare interactions in an examination. Teaching personnel often have had no formal training in communication skills themselves and may find the instrument provides useful criteria to apply when teaching and testing students.

The instrument differs from previous rating scales, such as the scale formulated by Maguire (Maguire et al 1978:695-704) in that it can be used to evaluate a wide range of health-care interviews, not only diagnostic or history-taking interviews. The focus is specifically on communication behaviours which can be taught. This emphasis is partly achieved through the six headings, which are deliberately worded as communication activities. In this way both the function and the desired consequences of the behaviours are immediately apparent. The way in which the behaviours have been organized also makes it easy for students to remember and use as a quick mental check while conducting an interview.

\section{The Development of the Instrument}

\section{Motivation}

The instrument was developed to meet a perceived lack in the literature on interviewing skills in Health Communication studies. It has been devised to cover most of the relational aspects in the communication interaction, while also including the transfer of information. It appears as Table I.

\section{Literature Research}

A broad survey of the research dealing with communication aspects of healthcare interactions was conducted and a comprehensive list of behaviours that had been shown to be characteristic of good patient-centred interviews was collated and categorised into six clearly defined and useful groupings. These were developed into a rating instrument for both trainers and nurses to use in this study. The intention was to be as comprehensive and consistent as possible in teaching and assessment, before, during and after training. The specific behaviours are rated on a 5-point scale as either positive (or "helping" the interview) or negative ("hindering" the interview).

\section{Description of the}

\section{Instrument}

The instrument consists of six categories of behaviours, which meet different needs of the patient. Each category consists of specific actions which are considered to either help or hinder the interview. These actions are rated positively (helping the interview) or negatively (hindering the interview) on a 5-point scale. The six categories of communication behaviours that have been identified by the authors are essential for a successful interview are:
1. Establishing rapport and respect
2. Listening receptively
3. Confirming the patient
4. Sharing control
5. informing effectively
6. Checking perceptions

In the sections that follow, the behaviours in each category of the instrument are described briefly.

\section{Establishing Rapport and Respect}

Establishing rapport with the patient depends largely on the care-giver's ability to display non-verbal behaviours which extend recognition to the patient. These non-verbal signals are the dominant part of the message which the patient receives from the care-giver. Patients are known to be highly sensitive to these non-verbal signals (Bush 1985:103-117). It is essential to establish a supportive communication climate from the beginning of the interview, in order to enable the patient to speak openly and to overcome tension and shyness. The caregiver should try to maintain a posture which indicates a relaxed, but alert, frame of mind. Through the expressive use of face, voice and gesture, an attitude of responsiveness, concern and involvement can be communicated. This expressiveness on the part of the caregiver has been identified as one of the major needs in patients (O'Hair et al:125129). Appropriate eye contact is important in establishing a sense of relationship, and every attempt should be made to avoid being distracted by medical 


\section{Listening Receptively}

Listening is a key element in the communication process (Wolff et al 1983, Van der Merwe 1991). Being receptive to the patient requires listening to the verbal message, as well as observing the nonverbal message. The patient's non-verbal cues convey feelings and emotions an important part of the patient's message to the care-giver.

The patient needs to feel that the interview is a conversation, so the interviewer's ability to hear and respond appropriately is important. Through the use of 'encouragers', like nodding, the caregiver indicates a desire for the patient to continue talking, and stimulates openness in the patient (Haggerty 1971:382391). Discouraging or inhibiting messages, such as doodling on paper should be avoided.

To get a full understanding of the patient, it is necessary to listen carefully for the patient's needs. The care-giver should not assume that he or she knows what the patient's experience is (Chubon 1989:23-38), but should ask questions to clarify the picture. Closed questions such as, "Do you feel better now?" are not likely to elicit a genuine response. Open questions such as "How do you feel now?" can give more insight into the patient's fears, problems and misconceptions (Pendleton et al 1984:8).

\section{Confirming the Patient}

Having listened well to the patient, and attempted to clarify the patient's position, the care-giver needs to respond in a way that makes the patient feel accepted and valued.

A confirming response is one that recognises the validity of the patient's reality, and does not place a value judgement on this reality (Garvin et al 1986:1. 19, Steyn, 1994). This does not mean that the care-giver agrees with everything that the patient says, but rather makes a genuine attempt to deal with the patient's experience and perceptions. Restating content, reflecting feelings, and encouraging are all examples of confirming responses.

Disconfirming responses destroy a supportive climate, making the patient feel defensive. Talking down to the patient, ignoring an issue raised by the patient, and dismissing a patient's understanding are examples of disconfirming responses (Garvin et al 1986:1-19)

To be able to respond in a confirming way requires that the care-giver should not be self-involved; and is a reflection of the care-giver's self-esteem.

\section{Sharing Control}

Most patients respond well to interactions in which there is a sense of equality and in which they share the responsibility for directing the interview (Burgoon et al 1987:307-324, Street et al 1988:420440, Korsch 1989:5-9). O'Hair (1989:97115) points out that patients are no longer passive participants in the healthcare relationship, but "are willing to assert themselves with messages that attempt control or neutralize control of the transaction". He sees the resurgence of malpractice litigation and treatment noncompliance as consequences of this desire for more communicative control. The extent to which patients are comfortable with increased responsibility has been linked to whether the patient has an internal, or external, health locus of control. Patients with an internal health locus of control are most comfortable with increased responsibility (Arntson et al 1989:75-95). To ensure that the real issues at stake for the patient are aired (Holt 1990:131-132), the patient should do more speaking than the doctor or nurse. Any problems can then be met with appropriate information. This does not mean that the interview should lack direction; the care-giver can use probing questions to keep the interview on track, and skilfully redirect the patient if there is too much digression. This redirecting should be done by openly telling the patient that this is what one is doing.

Whenever possible, the patient should be allowed to set his or her own goals to solve the problems that arise from the illness, thus taking a measure of responsibility for the cure. This requires that the care-giver should approach issues in the spirit of negotiation and partnership. Therapy thus negotiated with the patient is more likely to succeed (Korsch 1989:5-9).

\section{Informing Effectively}

Patients' satisfaction with medical treatment has been linked to their understanding of the information presented to them (Ley 1982:241-254). To be effectively received, information should be presented at the appropriate moment of the interview. The early stages of the interview should be used to release tension, and to establish a supportive atmosphere. An "agenda" for the interview should be negotiated with the patient. If this early part of the interview is done effectively, the objectives of the middle section of the interview can be better met, when the patient feels more at ease to talk about things that affect him or her deeply. When the patient feels able to talk openly the likelihood of identifying the real issues increases.
The information given to the patient should be appropriately pitched for the patient's level of understanding; unnecessary medical jargon, which is at best confusing, and at worst alarming, should be avoided. Moreover, since patients feel a great need for information (Kreps 1988:344-359), the doctor should not only inform the patient about the disease and the treatment, but also involve the patient in the problem-solving required to make a diagnosis. The information should be introduced at a pace that is appropriate to the patient.

The end of the interview should consist of summarising important information, and formulating an action-plan based on the point of view of both the care-giver and the patient. The responsibilities each has for the success of the treatment should be spelt out clearly.

\section{Checking Perceptions}

An analysis of care-giver-patient rhetoric shows that although both care-giver and patient may be addressing the same topics, they may miss each other completely (Sharf 1990:217-229).

The process of checking perceptions is most important to the success of the in terview. Health care professionals tend to be unaware of their patients' perceptions of health interactions, and yet it is the patient's perception that influences the outcome of the treatment. Health care professional's self-perception of their communication style has been shown to be irrelevant to the patient's satisfaction with the interaction (Street et al 1988:420-440).

A patient is more comfortable if the caregiver is perceived as being similar to him or her (Burgoon et al 1987:307-324). The care-giver should therefore try to work with the patient's perceptions, clarifying how the patient understands significant issues and using that understanding as a framework for explanation to the patient. This checking of perceptions should occur frequently throughout the interview.

At the end of the interview the care-giver can give a summary of his or her perceptions of significant moments in the interview, such as when the patient ap peared to be nervous, and ask for feedback on whether the issues are now resolved for the patient.

Checking the interview in this way not only ensures congruence of perceptions between care-giver and patient, but also allows for the development of rapport between care-giver and patient. Moreo ver, the care-giver gets an idea of his or her ability to conduct a patient-centred interview. This ensures that the care- 
giver obtains continual feedback on which future personal growth can be based.

\section{Case Study:}

\section{A communication train-} ing programme using the

\section{instrument}

The instrument was first used in a study on the quality of communication between nursing sisters and tuberculosis patients, at a TB day clinic in Mitchells Plain in the Western Cape (Steyn et al 1997:53). Five nursing sisters on the staff of the Clinic participated. They were not selected for any skills or history, but were the staff routinely allocated for duty on the day the study commenced.

In the study interactions between the nursing sisters and their patients were analysed using the instrument. Two video-recordings were made of each sister interviewing a newly-diagnosed TB patient; one made before and one after training in communication skills. The 20 hour training programme was given by the authors, all of whom were on the staff of the Professional Communication Unit at the University of Cape Town. The rating instrument was used in order to assess the effect of the training programme, and was done by six assessors. Two of the assessors were not directly involved in the project and did not know which of the video recordings had been made before and which after the training phase.

\section{Procedure Before and After Training}

The patients' permission was requested for the entire interview to be recorded on video. Interviews were conducted in an office in which the video cameras had been positioned so as to carefully observe both the nurse and the patient's face and body throughout the interview. Immediately after the interview a questionnaire was administered to the patients to obtain their impression of the interview. The nurses were also asked to rate themselves by means of a similar questionnaire. The intention was to provide nurses with feedback and opportunity for reflection on their own skill.

\section{The Training \\ Programme}

The training programme began with theoretical input on the principles of effective interpersonal communication, and the overall functional structure of an interview. The list of behaviours described in the rating instrument were explained in detail, and the reason for their significance. The Convergence Model of Communication (Rogers \& Kincaid) was found to be useful for illustrating the on-going, dynamic nature of the interview and the desired progression toward mutual understanding and equality.

\section{Role Plays}

Part of the training was done through role-plays. The following scenarios were used which deliberately focused simply on the emotional and social implications of the disease. Each nurse had the opportunity of taking the part of the nurse, the patient and the observer.

\section{Examples of Role-play Scenarios \\ Role Play One: \\ Patient's Information}

You are Anne, a 19 year-old girl, unmarried, with a two year-old daughter. Your own mother died of TB when you were very young, leaving you to be raised by other family members, with whom you still live. You are unemployed. You are frightened that this might happen to your child as you don't have any faith in the treatment. You've heard lots of stories about how people die of TB. You don't volunteer this information as you don't want to seem childish or hurt the nurse's feelings. Because of this, you act sullen, evasive and withdrawn.

\section{Nurses Information}

The patient in front of you is Anne, a 19 year-old unmarried mother with a daughter of two.

\section{Role-Play Two:} Patient's Information

Figure 1 : Rating by six assessors of nurses' communication skills before and after training.

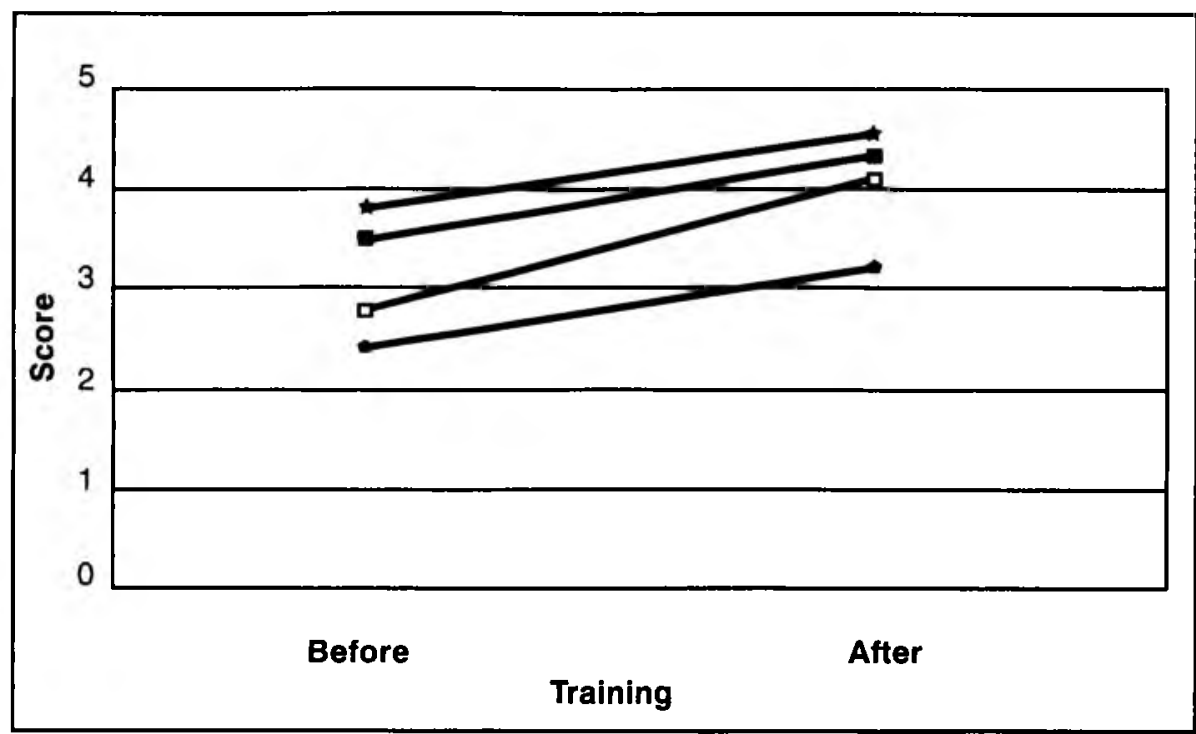

You are Mary, a 40 year-old char, working Mondays, Tuesdays and Fridays for different employers. You are divorced and have no other support. You live alone with three dependent school going children. You cannot possibly come to the clinic on these days for your medication as you would risk losing your jobs. You are not going to let your employers find out that you have TB.

\section{Nurses Information}

The patient in front of you is Mary, a 40 year-old mother of three.

\section{Use of Video in Training}

The role-plays were recorded on videotape and discussed by the nurses and the trainers. videotaped interviews with patients in the Mitchell's Plain Clinic, so that they could observe their own behaviour as well as the responses of their patients. They used the rating instrument to evaluate their own consultation skills and identify areas needing improvement. Discussion and peer evaluation was encouraged to give them as much helpful feedback as possible.

\section{Evaluation of the Patient Interviews} Recorded Before and

\section{After Training}

The two sets of videorecorded patient interviews were first transcribed from the tapes. In order to evaluate the nurses' performance as objectively as possible, six assessors were asked to rate the communication behaviours of the
The nurses were also shown their first 
nurses. Two assessors did the rating 'blind' in that they were not told whether they were watching the 'before or after' video recording. These assessors were communication teachers who were not otherwise involved in the study.

All the assessors used the rating instrument to assess the six categories of behaviour as either positive (helping the interview) or negative (hindering the interview) on a 5-point scale. In all a total of 1560 observations were made, a total of 26 for each nurse. The scores obtained are described in an earlier publication in Curationis (Steyn et al $1997 \mathrm{p}$. 54). The rating instrument was able to be used by all the assessors to judge the communication behaviours with enough understanding and consistency.

Figure 1 shows that all the nurses improved during the training period. The parallel profiles exhibited by the six assessors indicate that they were in good agreement.

However some differences did occur in the rating. For example, the two 'blinded' assessors involved in the study ap. peared more stringent in their evaluation of the nurses performance. Nevertheless, the scores demonstrate that the raters were consistent in finding the same trend to overall improvement; and in identifying the behaviours that were responsible for the trend.

\section{Conclusions}

1. Although research is needed to further validate the psychometric properties of this instrument, the use of six independent assessors does establish inter-rater reliability for the instrument.

2. The instrument was able to be used successfully by two "blind" assessors, which indicates that they were able to understand the terms used to describe the communication behaviours, and also able to identify and interpret these behaviours.

3. The degree of correlation between the scores of the six assessors in the case study indicates that they had been able to use the instrument with a degree of consistency and reliability. Although the "blinded" assessors appeared more stringent in their evaluation of the nurses, all the assessors were in good agreement using the rating instrument. (Steyn et al 1997).

4. No cross-cultural validation of the instrument has been done, and the instrument is as yet entirely informed by western research on the subject. The instrument should be used keeping this in mind. Further refinement and validation is now necessary.
5. Clearly the nature of communication in health-care interviews is such that it cannot be satisfactorily described by a mere check-list of behaviours. However, for the purpose of teaching, it is necessary to be able to convert this daunting complexity into a form that can be understood and applied. The instrument was found to be a useful tool for this purpose by both trainers and nurses at all the stages of this study.

6. The usefulness of the instrument is partly due to the way the material is organised. The six main categories each encompass a complex set of competencies and abilities and thus avoids being just a mechanistic checklist of superficial behaviours. The simplicity of the organisation also makes it easy to grasp and recall. 
ARNTSON P., MAKOUL G., PENDLETON D., \& SCHOFIELD T. 1989. Patients Perceptions of Medical Encounters in Great Britain: Variations with Health Loci of Control and Sociodemographic Factors. Health Communication, 1(2): 7595.

BORCHERD R. 1987. The Nurse as Communicator. S.A. Nursing, 2(11/12): 5-9.

BURGOON J.K., PFAU M., PARROT R., BIRK T., COKER R., \& BURGOON M. 1987. Relational Communication, satisfaction, compliance - gaining strategies, and compliance in communication between Physicians and Patients. Communication Monographs, 54: 307-324.

BUSH D.F. 1985. Gender and non-verbal expressiveness in patient recall of health information. Journal of Applied Communications Research, 13(2): 103-117.

CHUBON J.S. 1989. Personal Descriptions of Compliance by Rural Southern Blacks: An Exploratory Study. The Journal of Compliance in Health Care, 4(1): 23-38.

DIMATTEO M.R., HAYS R.D., \& PRINCE L.M. 1986. Relationship of Physicians' Non-verbal Communication Skill to Patient Satisfaction, Appointment Noncompliance, and Physician Workload. Health Psychology, 5(6): 581-594.

EVANS B.J., STANLEY R.O., \& BURROWS G.D. 1992. Communication Skills Training and Patients' Satisfaction. Health Communication, 4(2): 155-170.

GARVIN B.J., \& KENNEDY C.W. 1986. Confirmation and Disconfirmation In Nurse/Physician Communication. Journal of Applied Communication Research, 14(1): 1-19.

HAGGERTY V.C. 1971. Listening: an experiment in Nursing Nursing Forum, (4): 382-391.

HOLT A. 1990. Scandinavian Journal of Primary Health Care. Editorial, 8: 131-132.

KORSCH B, \& NEGRETE V. 1972. Doctor-patient communication. Scientific American, 227: 66-74.

KORSCH B. 1989. Current Issues in Communication Research. Health Communication, 1(1): 5-9.

KREPS G.L. 1988. Relational Communication in Health Care. Southern Speech Communication Journal, 53(4): 344-359.

LANE S. 1983. Compliance, satisfaction and physician-patient communication. In: R. Bostrum, ed. Communication Yearbook 7, Beverley Hills: Sage, 772-799.

LEY P. 1982. Satisfaction, Compliance and Communication. British Journal of Clinical Psychology, 21: 241-254.

LIVESEY PG. 1986. Partners in Care. The Consultation in General Practice. London: William Heinemann Medical Books.

MAGUIRE P., FAIRBAIRN S., \& FLETCHER C. 1986. Consultation Skills of Young Doctors. British Medical Journal 1986; 292: $1573-1578$.
MAGUIRE P., ROE P., GOLDBERG D., JONES S., HYDE C., \& O'DOWD T. 1978. The value of feedback in teaching interviewing skills to medical students. Psychological Medicine, 8: 695-704.

MAGUIRE P. 1990. Can communication skills be taught? British Journal of Hospital Medicine, 43: 215-216.

MARTEAU T.M., HUMPHREY C., MATOON G., KIDD J., LLOYD M.H. 1991. Factors influencing the communication skills of first-year clinical medical students. Medical Education, 25(2): 127-134.

O'HAIR D., O'HAIR M.J., SOUTHWARD G.M., \& KRAYER K.J. 1987. Physician Communication and Patient Compliance. The Journal of Compliance in Health Care, 2(2): 125-129.

O'HAIR D. 1989. Dimensions of Relational Communication and Control during Physician-Patient Interactions, Health Communication, 1(2): 97-115.

PENDLETON D., SCHOFIELD T., TATE P., \& HAVELOCK P. 1984. The Consultation: an approach to learning and teaching. Oxford: Oxford University Medical Publications, p.8.

REISER D.E., \& SCHRODER A.K. 1980. Patient Interviewing: The Human Dimension. Baltimore: Williams and Wilkins.

SHARF B.F. 1990. Physician-Patient Communication as Interpersonal Rhetoric: A narrative approach. Health Communication, 2(4): 217-229.

STEYN M., VAN DER MERWE N., BORCHERDS R., \& WILDING R.J.C. 1997. Communication with TB patients; A neglected dimension of effective treatment? Curationis, Vol 20 , No 1.

STEYN M.E. 1994.Communication competence in multicultural conflict : Confirming behaviours in dealing with difference and similarity. In Nieumeijer $L$ \& du Toit $R$ eds. Multicultural conflict management in changing societies. HSRC.

STREET R.L. JUN, \& WIEMANN J.M. 1988. Differences in how Physicians and Patients Perceive Physicians' Relational Communication. The Southern Speech Communication Journal, 53(4): 420-440.

STREET R.L. JUN. 1989. Patients' Satisfaction with Dentists' Communicative Style. Health Communication, 1(3): 137-154.

THOMPSON T. 1984. The Invisible Helping Hand: The role of Communication in the Health and Social Service Professions. Communications Quarterly, 32: 146-163.

VAN DER MERWE N. 1991. Listening - a Skill for Everyone. Cape Town: Arrow.

WOLFF F., MARSNIK N., TACEY W., \& NICHOLS R. 1983. Perceptive Listening. New York: Holt, Rinehart and Winston.

WYATT N. 1991. Physician-Patient Relationships: What do Doctors say? Health Communication, 3(3): 157-174. 


\section{Establishing rapport and respect (Non-verbal cues)}

Hindering the Helping the
Interview

\begin{tabular}{|c|c|c|c|c|c|c|}
\hline Tense & -2 & -1 & 0 & 1 & 2 & Relaxed \\
\hline Casual & -2 & -1 & 0 & 1 & 2 & Alert \\
\hline $\begin{array}{l}\text { Cold, impersonal, } \\
\text { unconcerned }\end{array}$ & -2 & -1 & 0 & 1 & 2 & Warm, friendly \\
\hline Aloof, distant & -2 & -1 & 0 & 1 & 2 & Involved, interested, concerned \\
\hline $\begin{array}{l}\text { Ignores or } \\
\text { creates tension } \\
\text { in patient }\end{array}$ & -2 & -1 & 0 & 1 & 2 & Relieves tension, uses humour \\
\hline $\begin{array}{l}\text { Neutral, impassive } \\
\text { wooden }\end{array}$ & -2 & -1 & 0 & 1 & 2 & $\begin{array}{l}\text { Expressive } \\
\text { (in facial expression, voice inflexion, gesture) }\end{array}$ \\
\hline $\begin{array}{l}\text { Does not establish } \\
\text { appropriate eye contact }\end{array}$ & -2 & -1 & 0 & 1 & 2 & Establishes appropriate eye contact \\
\hline
\end{tabular}

\section{Listening Receptively}

$\begin{array}{ll}\text { Hindering the } & \begin{array}{l}\text { Helping the } \\ \text { Interview }\end{array}\end{array}$

Unwilling to

$\begin{array}{lllll}-2 & -1 & 0 & 1 & 2\end{array}$

Willing

listen

to listen

$\begin{array}{llllllll}\begin{array}{l}\text { Ignores verbal } \\ \text { cues }\end{array} & -2 & -1 & 0 & 1 & 2 & \begin{array}{l}\text { Picks up } \\ \text { verbal } \\ \text { cues }\end{array}\end{array}$

Does not

acknowledge

non-verbal

cues

Discourages or inhibits patient (absence of encouraging responses or opportunities for patient to talk)
Ignores or is unaware of the patient's agenda (closed questions)

$\begin{array}{cccccc}-2 & -1 & 0 & 1 & 2 & \begin{array}{l}\text { Picks up non- } \\ \text { verbal cues } \\ \text { (to patients' } \\ \end{array} \\ & & & \text { feelings and } \\ & & \text { needs) }\end{array}$

\begin{tabular}{|c|c|c|c|c|}
\hline-2 & -1 & 0 & 1 & $\begin{array}{l}\text { Encourages } \\
\text { patient } \\
\text { to talk } \\
\text { (silence/non- } \\
\text { verbal } \\
\text { encouragers) }\end{array}$ \\
\hline
\end{tabular}

Respects

patient's agenda (asks open-ended questions/seeks clarification) 


\section{Confirming the Patient}

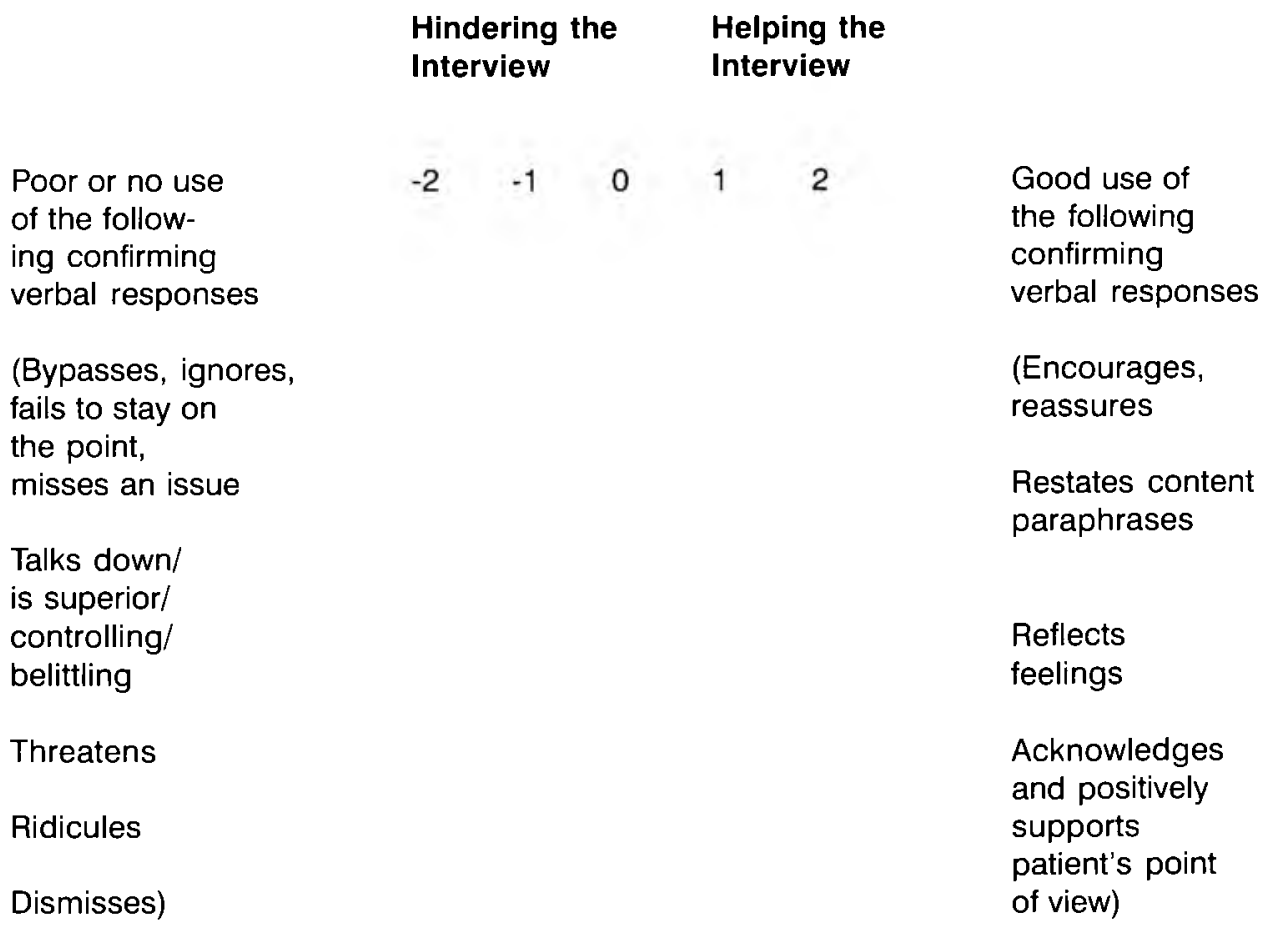

\section{Sharing Control}

$\begin{array}{ll}\text { Hindering the } & \begin{array}{l}\text { Helping the } \\ \text { Interview }\end{array}\end{array}$

Care-giver takes

all responsibility

Inappropriately

brisk/casual

Mechanical

approach

Inappropriate sharing of time (care-giver centred use of time)

Inappropriately paced/rushed

Inappropriately

directs

conversation

(interrupts, asks

leading questions)

Sets goals for patient (tells the patient)

\section{Hindering th Interview}

$\begin{array}{lllll}-2 & -1 & 0 & 1 & 2 \\ -2 & -1 & 0 & 1 & 2 \\ -2 & -1 & 0 & 1 & 2\end{array}$

$\begin{array}{llll}-1 & 0 & 1 & 2\end{array}$

$\begin{array}{lllll}-2 & -1 & 0 & 1 & 2\end{array}$

$\begin{array}{lllll}-2 & -1 & 0 & 1 & 2\end{array}$

$\begin{array}{lllll}-2 & -1 & 0 & 1 & 2\end{array}$

2
Patient given

share of

responsibility

Appropriately

formal

Flexible approach (allows patient spontaneity/ conversation)

Appropriate sharing of time (allows the care-giver to be in tune with patients needs)

Appropriately paced

Appropriately

directs conversation (probes, openly redirects)

Allows patient to set own goals (treatment negotiated with patient: covers psychological aspects, personal issues, social aspects) 


\section{Informing Effectively}

\begin{tabular}{|c|c|c|c|c|c|c|}
\hline \multirow[b]{2}{*}{$\begin{array}{l}\text { Inappropriate, } \\
\text { lacking in } \\
\text { format }\end{array}$} & \multicolumn{3}{|c|}{$\begin{array}{l}\text { Hindering the } \\
\text { Interview }\end{array}$} & \multicolumn{3}{|c|}{$\begin{array}{l}\text { Helping the } \\
\text { Interview }\end{array}$} \\
\hline & -2 & -1 & 0 & 1 & 2 & $\begin{array}{l}\text { Appropriate } \\
\text { format }\end{array}$ \\
\hline $\begin{array}{l}\text { Inappropriate } \\
\text { amount of infor- } \\
\text { mation for the } \\
\text { patient }\end{array}$ & -2 & -1 & 0 & 1 & 2 & $\begin{array}{l}\text { Appropriate } \\
\text { amount of } \\
\text { information } \\
\text { for the patient }\end{array}$ \\
\hline $\begin{array}{l}\text { Inappropriate } \\
\text { offloading rate } \\
\text { (too much/too } \\
\text { little information } \\
\text { for the time } \\
\text { available) }\end{array}$ & -2 & -1 & 0 & 1 & 2 & $\begin{array}{l}\text { Appropriate } \\
\text { offloading rate } \\
\text { (right amount } \\
\text { of information } \\
\text { for the time } \\
\text { available) }\end{array}$ \\
\hline $\begin{array}{l}\text { Inappropriate } \\
\text { pitch (unclear } \\
\text { vocabulary) }\end{array}$ & -2 & -1 & 0 & 1 & 2 & $\begin{array}{l}\text { Appropriate } \\
\text { pitch (clear } \\
\text { vocabulary) }\end{array}$ \\
\hline
\end{tabular}

\section{Checking The Interaction/Perceptions}

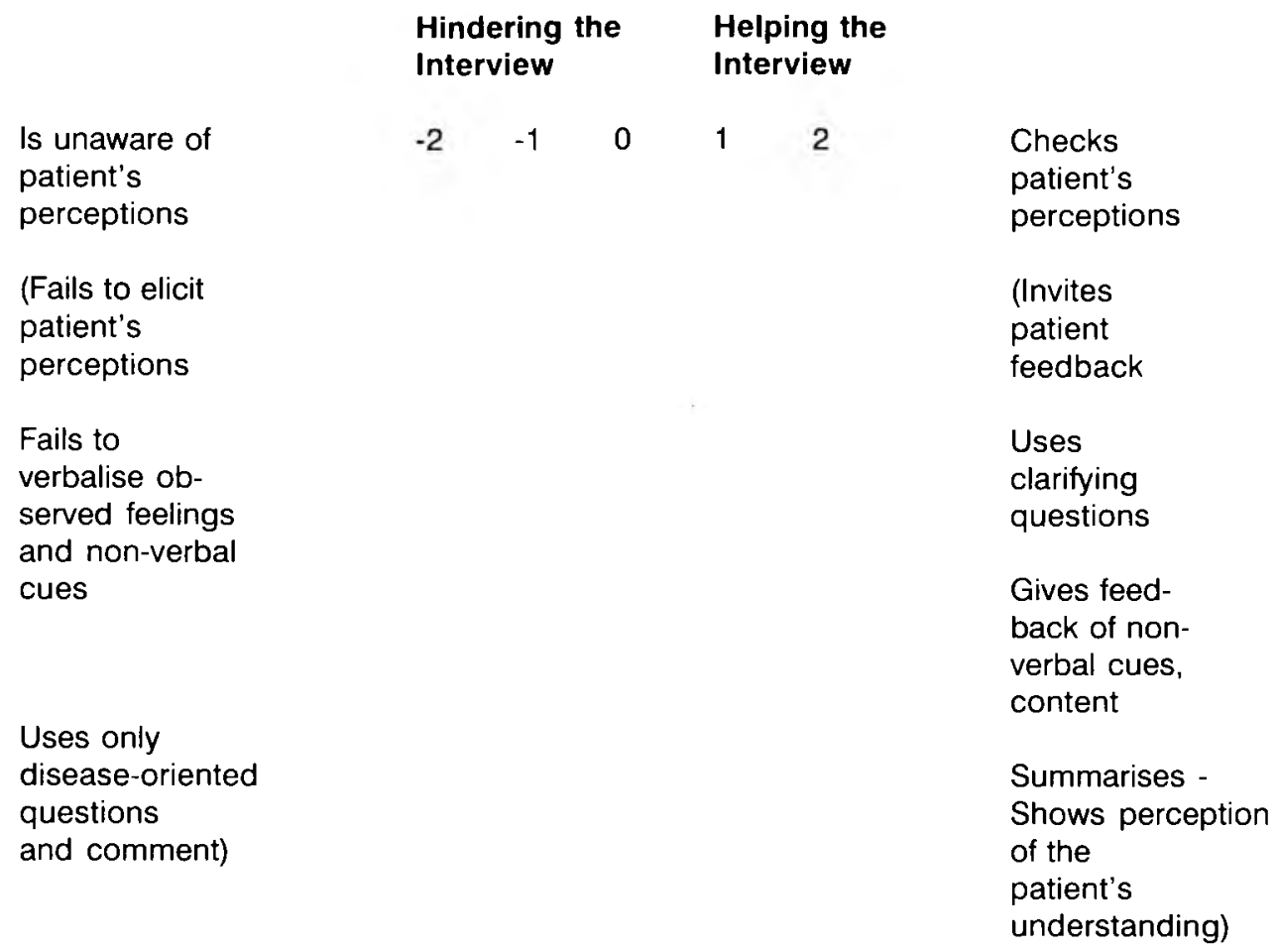

